\title{
THAI LITERATURES REFLECTING CHINESE IDENTITY IN THAI SOCIETY
}

\author{
Suchawadee Kesmanee \\ University Laboratory School Center for Educational Research and Development, Kasetsart University, Thailand
}

Received 2012-04-12; Revised 2012-04-13; Accepted 2014-01-09

\begin{abstract}
Literatures present the picture of people's lives in the society in details. There have been numerous studies on Chinese-Thai literatures but none of them has an in-depth study on the Chinese identity. This study has been conducted due to personal interest to analyze the authors' effort to present the Chinese identity through the characters, contents and social contexts. The data were collected from Thai novels and documentaries dated between 1957 and 2007 of which main characters, content and context were related to the Chinese residing in Thailand. Data collected had been inspected, classified, analyzed and composed. It was found that the Thai literatures could possibly represent Chinese identity in Thai society in the areas of the relationship of the family members from being a male-dominated family to a female-accepted one, the conservation of Chinese language to represent the unity of the Chinese community, the importance of the Chinese opera and its struggle to survive in recent times and the existence of Chinese culture and tradition, which are acculturated and assimilated to the Thai culture. From the study of Chinese identity in Thai literature in four aspects: (1) family relationships, system of relatives and surnames; (2) Chinese Language; (3) Performing Arts and (4) Culture and tradition, it was found that no matter how strict the first generations are to the traditions, they cannot resist the cultural assimilation in the next generations, who are descendants of Chinese overseas in Thailand. Since these new generations were born and grew up in Thai culture, which is different from the one of their ancestors, their versions of Chinese traditions were affected by the Thai society, economy and political situations which led to the changes of the old Chinese tradition and even result in the loss of some tradition.
\end{abstract}

Keywords: Chinese Family Relationships, Chinese Language, Performing Arts, Culture and Tradition

\section{INTRODUCTION}

Literatures present the picture of people's lives in the society in details. There have been numerous studies on Chinese-Thai literatures but none of them has an indepth study on the Chinese identity. This study has been conducted due to personal interest to analyze the authors' effort to present the Chinese identity through the characters, contents and social contexts.

\section{MATERIALS AND METHODS}

The data were gathered from Thai literatures from 1967 to 2007. Data collected had been inspected, classified, analyzed and composed.
Gathering concepts and theories from relevant documents and researches as follows.

\subsection{Concept of Identity}

Fiske (1991) which has been used to identity selection criteria such as Individual Identity is to answer the "Who am I?" question. Each individual person may have more than one identity depends on how they look at themselves. To be a member of several units in the society, each individual has different roles and can look at oneself differently from different aspects.

Collective identity refers to the process of creating socially shared consciousness and that would drive individual, as a social member, to realize their group common interest and that is another way of how they 
look at themselves by answering "Who are we?" question and understand how "Our group" is different from "Other group". The socially shared consciousness can be created and changed by using numerous symbols which have been built in group culture system, such as folk song. According to Schlesinger (1991) concept related to identity, society and culture have direct and important roles in creating, maintaining and adjusting identity. Hall (1997) suggests treating identity as a process in order to take into account the reality of diverse and ever-changing social experience. Some scholars have introduced the idea of identification, whereby identity is perceived as made up of different components that are "identified" and interpreted by individuals. The construction of an individual sense of self is achieved by personal choices regarding with whom and what the individual would associate with. Such approaches are liberating in their recognition of the role of the individual in social interaction and the construction of identity. Furthermore, Hall suggested in "circuit of culture" that identity is produced, consumed and regulated in the culture, which also creates meaning through the symbolic systems which represent one's positions in the society that can be used to create one's identify. The circuit of culture, which comprises of five moments, demonstrates how any cultural product is imbued with meanings. The five moments are (1) Regulation encompasses the formal and informal controls on culture; (2) Producers encode dominant meanings into their cultural products; (3) Representation is the form cultural products take, including the meanings encoded into them; (4) Consumers actively create meanings by using cultural products in their everyday lives and (5) Public relations practitioners serve as cultural intermediaries, working to create common identities between products or issues and consumers.

\subsection{Concept and Theory of Ethnicity}

Barth (1969) defined ethnic group as a type which people select to present themselves who they are. From Barth's standpoint, ethnic identity study or the selection process of social member in presenting who they are and which group they belong to is important because ethnic identity focuses on the importance of people interactions and cultural characters of ethnic which can be changed. Cohen (1985) view is interpretive and experiential, seeing the community as a cultural field with a complex of symbols whose meanings vary among its members. He delineates a concept applicable to local and ethnic communities through which people see themselves as belonging to society. The emphasis on boundary is sensitive to the circumstances in which people become aware of the implications of belonging to a community and describes how they symbolize and utilize these boundaries to give substance to their values and identities.

Furthermore, according to Kunstadter (1967), Ethnic Group means a group of individual people who have the same conscious and interest or have the same value. Ethnic Identification is defined as a process of determine characteristic as a criteria to accept people as a group member.

\subsection{Concept and Theory of Diaspora}

Cohen (2008) maintained that the concept of a diaspora can be applied when members of an 'expatriate minority community' share several of the following features:

- They, or their ancestors, have been dispersed from an original centre to two or more foreign regions

- They retain a collective memory, vision or myth about their original homeland including its location, history and achievement

- They believe they are not-and perhaps can never befully accepted in their host societies and so remain partly separate

- Their ancestral home is idealized and it is thought that, when conditions are favourable, either they, or their descendants should return

- They believe all members of the diaspora should be committed to the maintenance or restoration of the original homeland and to its safety and prosperity

- They continue in various ways to relate to that homeland and their ethno communal consciousness and solidarity are in an important way defined by the existence of such a relationship

The Chinese Diaspora in Thailand (also referred to as the Overseas Chinese or the Chinese Overseas in Thailand) represents one of the largest group of migrants in Thailand. They are dispersed from but are still related to their homeland through communication, reminding and telling of the stories of the homeland and of how they were dispersed from one generation to the next.

\section{RESULTS AND DISCUSSION}

The results revealed that the time period between 1967 and 2007 can be categorized into 3 periods:

- Before a change to Constitutional Monarchy or democratic regime in 1932, could be divided further 
into 2 periods. The first one was before an enactment of the Private School Act of 1918 and the second one was after the promulgation of the 1918 Act

- After a change to Constitutional Monarchy or democratic regime in 1932 until the end of Prime Minister Poh. Phibulsongkram's Administration (1956-1932)

\section{- 1956 to present}

The results revealed that the ancestors of the Chinese settling down in Thailand were the Chinese residing in the South and Southeast of China. They were not welleducated farmers whose lifestyle and way of living reflected their beliefs in Taoism, Confucianism and Mahayana (a sect in Buddhism). The concepts of the 3 doctrines were the natural spirits, rituals and moderate way of life respectively. Their beliefs were displayed in rituals which were performed to strengthen the sense of communal unity and the need to help one another. The Chinese, even after immigrating to a new land, have always been very strict to observe the tradition despite the political crisis, social changes and ethnic integration. Their beliefs and these social activities were signs of cooperation and key roles to lead their lives, work and maintain well-balanced emotional stability.

The mechanism and methods used by the Ethnic Chinese Thai to conserve their Chinese identity through rites included family elders acting as model, consultants or instructors, religions leaders passing on concepts and beliefs, relatives giving advices and chances to learn through rite participation, community organization and groups arranging activities to reinforce the cultural identity.

It was found that the Thai literature could represent the Chinese identity in the Thai society in four areas:

- The relationship of the family members, kinship and clan

- Chinese language

- Chinese opera

- Traditions and Cultures

\subsection{The Relationship of the Family Members, Kinship and Clan}

It was found that a traditional Chinese family generally consisted of at least two generations of people including husband and wife and children and universally the phenomenon of three generations, four generations and even five generations living under the same roof existed. A big family was often held in great esteem. The head of the household, the eldest male, had great veneration and respect for age and his determination to sustain and increase the family's wealth and status. The male remained head of the household while women left her own families to join her husband's family when she got married. All property was passed down through the male lineage. The status of women was low. There was great pressure for women to produce a son. In addition, wealthy men often had multiple wives and concubines to display their status. Some of this was due to Confucianism, which utilizes hierarchy and clear rules to stress harmony, stability and filial piety.

Besides, there were the Chinese inheritance and the family structure system. The practice of ancestor worship was practiced only by ones on the male side of the family. Only people who had done good deeds had the right to set up their ancestral soul label on the ledge.

However, the structure of the modern Chinese family has changed after the Communist Revolution with families generally becoming smaller and more nuclear. Nowadays, more and more adults move out, leaving their elder parents alone. Many young couples now live with their parents not for the family tradition, but rather because they cannot afford to buy a house or rent an apartment.

Today, girls as well as boys are valued. Women now do many kinds of work outside the house. For many young households, both husband and wife have their share in the shopping, housecleaning, cooking and caring for the children to show that they believe that both sexes are equal. Some of the older generations may still show slight hope for a grandson or great-grandson and disappointment if the outcome is a granddaughter, but in the end they love and value the child equally whether it is a boy or a girl.

\section{Example}

In the past, the feeling of dislike toward daughters had been a serious issue in the Chinese society. Since China has been an agricultural country, each family requires many labours to work in the field and their children can contribute as the main resource. Actually, a daughter can be as hard working or even more than a son. Yet, why daughters were considered unwanted by their parents? The reason is, according to Chinese tradition, when a woman gets married, she has to move out to stay with the husband's family. This was considered as a lost to the bride's family. Most people believed that having daughter was useless since they had to raise their daughter up to serve another family, not their own. On the contrary, the sons, who are considered 
as the main strength of the family, will also bring women from other families to serve them. These days, men do not get married just to have someone to stay at home or take care of the house chores. They are now looking for a smart woman who can work and make a living. She is expected to stand equally by his side, not just to serve like in the past. These days, women are no longer valued by their house-keeping skills, but rather by their ability at work (Burapa, 1993).

\subsection{Chinese Language}

The results revealed that when the number of the Chinese population increased there was a need for a school for their children to study Chinese language. Before Chinese schools were established in Thailand, most Chinese preferred to assemble together to learn Chinese at a Chinese shrine, hire a teacher to teach their Children at home or send their Children back to study in China, (in this case) school was the medium that related the Chinese offspring who were born in Thailand to China, the homeland.

During the first period, though there was evidence that the first Chinese School was established during the reign of King Rama1, in Koh Rian, not much detail was available. This school taught only Chinese language (Suppasopon, 1983).

On September 30, 1852, a boarding school of which students were taught in Chinese was established. The Chinese teacher who was one of the missionaries named Sinsae Ki-ang Qua Sean was its teaching manager. However, after he died in 1860, the teacher named Kaew, who took over the teaching job, changed the medium language in school from Chinese to Thai. The Chinese teaching school was thus dissolved ever since (Suppasopon, 1983).

Later in the reign of King Rama V, the Chinese in Thailand had also established Chinese schools in accordance with those of a Western pattern. This resulted from the fact that the Chinese wanted their offspring to be educated. Furthermore, there was a political conflict in China, which made various political factions in China and launch political campaigns in Thailand to get support from the Chinese in the country. This, in turn, encouraged the Chinese to become more and more aware of Chinese Nationalism and provided assistance to these political factions in order to carry out political activities in China. The political group that had played a key role in an establishment of Chinese schools in Thailand was the revolutionist movement led by Dr. Sun Yat-sen. The Chinese school named "Hua Iah" was established on
Captain Bush lane, Charoen Krung Rd., Bangkok. It was set up due to a political reason related to China's internal politics. Unfortunately, Hua Iah School was subsequently abolished when its teachers had no time because they had to travel to different places to promote their support for the Chinese revolutionist movement.

As the number of Chinese school in Thailand increased and got more involved in political activities in China, the Thai government during the reign of King Rama VI was well aware of the need to take control over Chinese school. Chinese schools were required to be registered in order to get the government subsidy. Via this approach, the state was able to inspect and control them.

In 1918, the Private School Act was passed stipulating that all private schools had to be enrolled and be under the supervision of the Ministry of education. The main objective of the Act stipulated the schooling in a private school that its students must be able to write and comprehend Thai fairly fluently and have to at least study civic duties as well as instil loyalty to Siam and knowledge of landscape, including town chronicle and geography.

Furthermore, private schools' teachers were required to know Thai and the state had the authority to forbid the usage of textbooks or educational instruments that were derogatory to population, or that made one distracted or lose one's social etiquette (Suppasopon, 1983).

The Act showed that the state of absolute monarchy at that time did not only prevent the Chinese schools from training their students to be solely aware of Sinoism but also encouraged the teaching of the stories of Thaism, which went in accordance with King Prajadhipok' statements which was delivered during his visit to Jin Tek School in 1927:

For your school, you may teach your students to love your motherland of China. This is very normal and should be encouraged. But apart from teaching them to adore China, I sincerely anticipate that they should be taught to love Thailand as well since all of you here have all privileges as the Thai people do (Suppasopon 1983).

Therefore, it is obvious that the Thai state from the Coup of 1932 to Prime Minister Poh. Phibulsongkram's administration was very strictly and seriously controlled Chinese schools. This decreased the number of Chinese school and eventually, there were not any Chinese schools left in Prime Minister Poh. Phibulsongkram's administration. According to the foregoing policy of the 
Thai state, Chinese people were unable to arrange their own education. This caused Chinese people to be unsatisfied. However, they could not express their dissatisfaction because at that time the Thai state was very strict and China was weak. After World War II, China became one of the five most powerful nations and Thais and Chinese have mixed cultures and lifestyle at the time. Chinese and Thais were not easily identified. With this good blend, there was no conflict as there was in the past. The Thai government relaxed the rules in order to promote a private sector to invest in education. Chinese language was allowed to be taught $10 \mathrm{~h}$ per week as a special experience subject. The language instructors were native speakers.

Nowadays, Chinese school development trend is that Chinese language is vital for business, industries and tourism. Thailand has a long history of diplomatic relationship with china. As China has opened her country, there are more opportunities for Thailand in trading, investment, education and cultural exchanges between the two countries. The people who know Chinese will gain advantage in terms of education opportunity and future career. Schools should acquire more Thai teachers to teach Chinese in order to avoid the political problem as happened in the past. Chinese schools should work with Chinese experts in conducting research to expand the knowledge of Chinese.

\subsection{Chinese Opera}

Chinese Opera or theatre, which is called "Gniou" in Thai, has been regarded as a social drama that reflects phenomena empirically existing in societies through its various components. As it is played by Chinese, it is closely related to Chinese identity in Thai society. It is found that the importance of Chinese Opera in Thailand, which is normally showed around Thailand, is that it is relate to Chinese shrines and usually played in Chinese shrines. Change of Chinese Opera can be seen in the shift of its role from worshiping purpose to entertaining purpose and also its function to help to create a sense of belonging among members of the communities. There might be two main reasons for this. Firstly, the show uses Chinese as the medium because it is the language that overseas Chinese people can understand. However, the audiences of younger generation have trouble understanding because they are not used to the intonation of singing and the conversation during the show. Secondly, the function of Chinese opera was originally to worship supernatural beings. The Thai audience and younger generation Chinese audience might have little understanding of this. However, they are able to appreciate the beautiful costumes and the actors' lyric voice. At present, Chinese identity has been revived with new meanings to include Thai cultural component, not only language.

The opera reflects Chinese identity in emphasizing Chinese family values based on Confucius and Taoist teachings. Chinese identity and community ideological patterns can be represented through symbols employed in Chinese Opera. Thus the opera, substantially confirms the existence of Chinese community, which continues to exist even after the show in the form of shared values which can also be seen as part of the enculturation process in maintaining Chinese identity.

However, Chinese Opera has lost its popularity as seen in decreasing number of the shows, performers and the money spent for costumes, which leads one to question its potential to survive. The study confirms that Chinese Opera will continue to exist as part of the Chinese community as long as the Chinese hold a strong commitment towards their shared values in religious belief and worship or ancestors. Chinese Opera or "Gniou" performances are not dying. Now most actors are Thais coming from "Isaan" (north eastern part of Thailand). "Gniou" performances are made to offer a gift to Chinese gods. So now performances are often made in front of a non-living audience.

Nowadays, performing arts of Chinese Opera in Thailand has developed and adapted to change the type to be creative and fit with the modern world. It is widely recognized as the art of weaving the cultural mix that you have seen anywhere in the world.

\section{Example}

B.E. 2475 (1932 AD) after the Siamese revolution, all the entertainments had been banned and all the performance had been cancelled. Only the performance at Changxin Theatre remained. Chang was very tense due to a huge lost of the income. By the end of B.E.2483, during the Second World War (1941-1945), the situation was getting worse in the capital. Many university students and civilians joined in the protest, demanding the government to claim the territory back from France. People gathered and exchanged their opinions on the issue widely until the government prohibited the public gathering along with many restrictions. This also forced Chang to stop the performance and people in his troupe left to find other jobs (Kennasingha, 1970).

Think about it, it's been over ten years now. Elderly Chinese people in our community who are our main audiences are getting fewer and fewer; either they passed away or they were sick and just could not leave the house. The young ones who used to come to Chinese 
opera with their parents must have grown now and they are more interested in ballrooms, cinemas, or plays and in the future, they will just stay at home watching television (Kennasingha, 1970).

He has no idea how far the Chinese Opera has gone nowadays, but he knows that the theatre has been improved with modern techniques such as lighting. The sound system is also better. The performers look more modern as well. Everything must keep improving, otherwise it will be degrading (Sukda, 2002).

These days, some of the Chinese opera audience come from Isaan region (North-eastern part of Thailand) especially the female maids. They usually stop by for Chinese opera in the afternoon after finish their grocery shopping at the market since it's too early for the openair cinemas (which usually run in the evening). Most of the male performers are also from the same region. Occasionally, they might sing the country song or speak in local Thai dialect which is more entertaining for both the performers and the audiences. This is the unique style of day-time Chinese opera performed in Thailand (Kanokpongchai, 2004).

\subsection{Traditions and Cultures (8 Annual Traditions and 5 Rites of Passage)}

The results revealed that most of the Chinese people mixed their rituals with their religious belief, which was the combination of Buddhism, ancestral worship, Taoism, Confucius and theism. Bound by their religious beliefs, the Chinese practice religious rituals because they are expected to behave properly in society and in the family as well. The Chinese cultural can be divided into 2 dimensions which are annual traditions and rites of passage.

The annual traditions and rites of passage reflecting Chinese identity are as follows.

\subsection{The Annual Traditions}

The annual traditions have 8 major festivals. Those festivals are:

- Chinese New Year (Chinese: 春节; pinyin: chūn jيe), often called Chinese Lunar New Year although it actually is lunisolar. It marks the end of the winter season, analogous to the Western carnival. The festival begins on the first day of the first month in the traditional Chinese calendar and ends with Lantern Festival which is on the fifteenth day

- The Lantern Festival tradition (Chinese: 除夕; pinyin: $\operatorname{ch}^{\circ} \bar{x} \overline{1}$ (or Chinese New Year's Eve, a day where Chinese families gather for their annual reunion dinner, is known as $\mathrm{Ch}^{\circ} \mathrm{x} \overline{1}$ (除夕) or "Eve of the Passing Year". Within China, regional customs and traditions concerning the celebration of the Chinese New Year vary widely. People will pour out their money to buy presents, decoration, material, food and clothing. It is also the tradition that every family thoroughly cleans the house to sweep away any ill-fortune in hopes to make way for incoming good luck. Windows and doors will be decorated with red paper-cuts and couplets with popular themes of "happiness", "wealth" and "longevity". On the Eve of Chinese New Year, supper is a feast with families. Food will include such items as pigs, ducks, chicken and sweet delicacies. The family will end the night with firecrackers. Early the next morning, children will greet their parents by wishing them a healthy and happy new year and receive money in red paper envelopes. The Chinese New Year tradition is to reconcile, forget all grudges and sincerely wish peace and happiness for everyone

- Tomb Sweeping Day/Mourning Day/Ching Ming Festival solar longitude (Chinese: 清明节; pinyin: qīng míng jié): 104 days after winter solstice (around April 5) when the weather is clear and bright; sober and calm. Chinese people visit, clean and make offerings at ancestral gravesites, which is also the opportunity for family's spring outing

- Duanwu Festival (Dragon Boat Festival)/Tuen Ng Festival duānwǔjié (Chinese: 端午节; pinyin: duān wŭ jié): the $5^{\text {th }}$ day of the $5^{\text {th }}$ lunar month. Duanwu Festival (Dragon Boat Festival)/Tuen Ng Festival, involves Dragon boat race, eating dumplings wrapped in lotus leaves Zongzi. This festival commemorates the ancient poet Qu Yuan; drink yellow rice wine, related to the White Snake Lady legend

- Ghost Festival (Chinese: 中元节; pinyin: zhōng yuán jié) or Chinese Sart Festival: The Chinese Sart Festival is on the 15th day of the 7th lunar month in the Chinese calendar. Chinese people burn fake paper money and make offerings to ancestors and the dead to appease them, so that they will not trouble the living. This Festival is an important day for Chinese children to express their gratitude to their ancestors. The ceremonial offerings are to pay homage. It is considered that the doors of hell are open to the Spirit shall be given to charitable deeds

- Mid-Autumn Festival (Moon Festival) (Chinese: 中秋节; pinyin: zhōng qiū jié): 15th day of 8th lunar 
month of the Chinese luni-solar calendar (usually around mid-or late-September in the Gregorian calendar), a date that parallels the Autumn Equinox of the solar calendar. At this time, the moon is at its fullest and brightest, marking an ideal time to celebrate the abundance of the summer's harvest. The traditional food of this festival is the moon cake, which comes in many different varieties

- Vegetarian Festival (Nine Emperor Gods Festival (Chinese: 九皇爷; pinyin: jiǔ huáng yé): The 9th month of lunar calendar of every year that the Chinese descendants in Thailand celebrate "Vegetarian Food Festival". The festival is actually renamed from the Nine Emperor Gods Festival. Its devotees will practice vegetarianism throughout the 9 day-long festival plus one day on the eve of the festival

- Chinese New Year's Eve (Chinese: 除夕; pinyin: chúxī): The last night of the year in the Chinese lunar calendar, when Chinese bid farewell to the old year and usher in the New Year. This is the time for family members who are unable to see each other due to busy schedule, to gather and have a nice meal

Thai literature represent that most Chinese in Thailand are attached to these 8 major festivals as Konuntakiet (2006) mentioned in "Tungnangkia" (Chinese: 唐人仔; pinyin: táng rén zǐ) that "The two ways to pay respect are to pay respect to god and ancestor worship. In some Thai houses, there is a small Chinese shrine to worship gods. Even some Thai people, who have no Chinese roots, have a Chinese shrine at home. The shrine is usually red in colour and set on the floor. It represents the god who controls the ground upon which the house is built. This shrine is called 'Tee-Ju-Iya'. In the morning, some of the tradesmen may visit and worship the 'Pung Tao Kong' or the goddess of fortune's shrine to ask for profit and prospering trade and worship ancestor later".

\subsection{Rites of Passage}

Rites of passage have 5 rites. The details are as followed:

- The protecting spirit rite (Aok Deun, Chinese: 满月; pinyin: măn yuè). As the beginning rite of one's life, rite of birth consists of a series of ceremonies including praying for a son, fetus protection, labor, as well as praying on three mornings: First month, first one hundred days and one full year of a baby's life. All the prayings are for the new-born baby to be blessed and for the evil spirits to be driven away from the mother. Rite of birth is an embodiment of people's recognition of reproduction and their favorable expectation of life. Lots of customs involved in the rite are the embodiment of traditional Chinese culture.

Example of Ceremony for the Newborn:

- 'A-pua' is believed to be the lady spirit who protects the children, like a babysitter. This is similar to the belief of "Por-sue", "Mae-sue" in Thai culture. For the Chinese, when a child is born, the parents will arrange a ceremony at home, make offerings to the guardian spirits of the house and pray for 'A-pua' to protect the new born until he or she grows up. Some people may go the pray to 'A-pua' at Wat Leng Nei Yee (Dragon Flower Temple in Bangkok) (Konuntakiet, 2006)

- Rite of passage [(Chook Huay Heu) 出花园 (chū huā yuán)]. For centuries, a Chinese baby's first year was passed with bated breath. China's high infant mortality rate meant that if a baby made it to its first birthday, it was much more likely to survive. Therefore, this milestone is much more important than any other birthday and the most appropriate time for celebration and the "zhua zhou" or the birthday grab

\section{Example of birthday ceremony:}

"Father, why don't you organize a birthday party for me like others?"

"It's useless and such a waste of money. Wait until you turn fifteen and I will arrange a blossom ceremony for you: Make a spirit offering and get together for a feast amongst our relatives. We can also make merit and charity. At least that can help others in need. But I disapprove inviting lots of friends for a party at home (Sirisingha, 1999).

- Wedding rite (婚姻 hūn yīn). On the morning of the wedding day, the groom is symbolically dressed by his parents. The groom arrives at the house of his bride on the way to the wedding chapel. He brings gifts of cash, wrapped in red tissue, to give to his bride's friends, in exchange for "letting her go". In some families, the wedding couple serves tea to both sets of parents while kneeling in front of them, a symbolic gesture of asking for permission. The bride and groom then leave for the wedding site together 
Example of the wedding ceremony:

"These are accessories for the bride when she's leaving her house. Those...money deposit box, kerosene lamp, pillow, wedding veil, blanket, actually there must be a mattress but it's quite large so we just use the small items and in that pack is sewing kit. The thing in that bag is called 'the first wife's bib'. It is like a infant's apron but larger. The bib was made of fine scarlet silk. Its strings are made from real gold. Nuts, sesame seeds and plants which are considered auspicious are put inside the front pouch of the apron".

Thong's car was decorated with pink silk on the front hood and on the front windshield there were stickers of Chinese characters. Before the couple got in the car, they were sprinkled with holy water. Thong led his wife into the back seats.

"Where is your mother?" Worrarat whispered to Thong. She hasn't seen his mother since she entered the house.

"She's hiding inside. According to the Chinese tradition, the mother and daughter in law must not meet until the dawn." Thong took her upstairs to a room which there was a shrine at one side of the wall. In front of the shrine there were offerings such as pork, duck, chicken.

"First, we pay respect to the gods" Thong said while he was lighting the incense sticks for his bride. "Then, we pay respect to our ancestors in the room over there" Thong then took her to meet his relatives downstairs. Worrarat met her mother in law at last (Roojjana, 1980).

- Celebration on the sixtieth birthday (Sae Yid) (生日 shēng rì). The reason for the large celebration is that the sixtieth birthday is one of the few celebrated in Chinese cultures and comes with much fanfare. The sixtieth birthday is celebrated because it means a person has lived a long life. When their parents turned sixty they held big birthday celebrations for them and celebrated their lives

Example of the Sae-Yid ceremony (sixtieth anniversary of age):

Chinese usually celebrate their fiftieth or fifty first anniversary of age called 'Sae-Yid' which is considered important and will take place every ten years. If the first ceremony is arranged on the fiftieth anniversary, the next one will be on sixtieth, seventieth, eighties and so on. Likewise, if the first one is on the fifty first, the next one will be on sixty first, seventy first and eighty first. The other anniversaries are not considered special. Grandfather's Sae-Yid ceremony this year was organized by Aunt Ngeg-Ju, Peng's mother. She is very strict to the tradition. When she knew that this year her grandfather is going to turn seventy years old, she went to talk with the elderly people in the area and they all agreed to organize Sae-Yid ceremony for grandfather since he is the most senior in this market. Everyone realizes that he has been honest and hard working and he is the most respectful person in the community. Since they all insist to organize this ceremony for him willingly, he can't turn them down (Burapa, 2005).

- Burial rite (Chinese: 功德; pinyin: Gōng dé). The burial of the dead is a matter taken very seriously in Chinese society. Improper funeral arrangements can wreak ill fortune and disaster on the family of the deceased. To a certain degree, Chinese funeral rites and burial customs are determined by the age of the deceased, cause of death, status and position in society and marital status. According to Chinese custom, an elder should never show respect to someone younger. So, if the deceased is a young bachelor, for example, his body cannot be brought home and must remain at the funeral parlor. His parents cannot offer prayers to their son, either. Since he was unmarried, he did not have any children who could perform these rites so (his body cannot come into the family home). If an infant or child dies, no funeral rites are performed either since respect cannot be shown to a younger person. The child is thus buried in silence. Funeral rites for an elder must follow a prescribed form: Rites befitting a person's status, age must be performed even if this means the family of the deceased will go into debt.

Example of the funeral ceremony:

"It is the duty of the son. If your father is still alive, he would have to do it. Usually the son shaves their head next day after his parent passed away. Then get the holy water from the temple to bath the body and dress the body as well. The family member has to wear a gown made from sackcloth with a hat decorated with pendants and wear an unbleached cloth inside. It's a bit itchy 
but you have to bear with it every day. Every morning use a clean piece of cloth soak with the holy water from the temple to clean the face of the body. Before doing so, you have to call the dead person's name to let him or her know that you are going to clean his or her face. Then set up the offerings for the spirits. There are a lot of rituals but they have been done for many generations so we have to carry on. The rituals of washing the face of the body and setting up the offerings last just two days and then we put the body in the coffin and that's all. But we keep the body for a hundred days before move the body to the graveyard! Just before seven o'clock the next morning, grandmother Prang's body arrived at the western building. The lamp was lit and put by her feet. Grandfather washed his wife's face by himself and then dressed her up with the help of aunt Prao and aunt Ying. Onsurang counted the clothes from the first layer which was quite tight, to the outer layers which were quite loose. Finally, the thirteenth cloth was put on the body. It was a traditional Chinese costume made from satin which was ravishingly decorated.

The next day, Onsurang was on duty to make tea so she had a chance to see A-Yun perform a ritual by washing the face of the body and set up the offerings in the traditional way. "Tomorrow they will put the body in the coffin, you should see it. The ceremony is quite long. At night, there will be "Kong-Tek" ceremony. Five Chinese monks will be chanting. People who can understand the chant might cry since it says about a mother's kindness for carrying the baby in her womb for 10 months. In front of the body, they will place ten glasses filled with red liquid, symbolizing blood for each month of her pregnancy. But we don't understand so we won't be that sad. After the monks finish chanting, we still have to serve meals to the guests".

In the ceremony, the family members are given priorities according to their seniorities: The eldest son comes first, follows by the other sons. Next are the daughters in law, who are given more priorities than their own daughters since the daughter in law married into the family while their own daughters married out of the family. After the daughters come the sons in law. The last are the grandchildren: Starting from the grandsons and granddaughters and finally finishes by the great-grandchildren (Woradilok, 1994).
The rituals were inherited to the younger generation through the rituals the older generation performed annually in their families. There were differences in both pattern and meaning practiced among three sequent generations. For people of the first generation, the rites were exactly practiced as the originals. However, some rites of the second and the third generations had been adapted to be more convenient and appropriate for their environment. Sometimes certain rite was conducted without realization of its original meaning. The modification of the rituals began to be found in the families which did not accurately inherit their rituals to their children. The inaccuracy caused the modification of some ritual forms for different occasions. Then, these gradually caused the modification of the rituals' details. In addition, the higher those descendants educated, the more likely it was for the traditional rituals which did not serve the modern social needs to disappear. Moreover, the more those youth were easily exposed to Thai culture, the less they earnestly involved in their original accurate ritual procedures. They tended to reduce some procedures and details of the original rituals. The factors in economy, education, religion, communications and the advance of science and technology also affected the ritual performance to become more practical and meaningful to the Thai society, culture and religion. Thus, the modification of Chinese culture gradually made it more harmonious to the Thai society.

These represent that the mechanism and methods used by the Ethnic Chinese Thai to conserve their Chinese Identity through rites included family elders acting as models, consultants or instructors, religions leaders passing on concepts and beliefs, relatives giving advices and chances to learn through rite participation, community organization and groups arranging activities to reinforce the cultural identity.

For the image of Chinese identity among the Ethnic Chinese Thai in Thai society as a whole, some parts of it had been assimilated to main culture while some of its originality remained. There was also the sign of restoring Chinese identity through social mechanism both directly and indirectly.

\section{CONCLUSION}

From the study of Chinese identity in Thai literatures in four aspects: (1) family relationships, system of relatives and surnames; (2) Chinese Language; (3) Performing Arts; and (4) Culture and Tradition, it was found that no matter how strict the first generations are to the tradition, they cannot resist the cultural assimilation in the next 
generations, who are descendants of Chinese overseas in Thailand. Since these new generations were born and grew up in Thai culture, which is different from the one of their ancestors, their versions of Chinese tradition were affected by the Thai society, economy and political situations which led to the changes of the old Chinese tradition and even result in the loss of some tradition.

The more the age difference between the two generations is, the more the difference in the culture and tradition are. But one thing that has never been changed is that the Chinese and the Chinese descendants in Thailand always teach their children to be grateful and show gratitude towards their benefactor, which is a good value in their tradition.

The benefits of the research were as follows:

- To collect and create intimate knowledge of Chinese identity in Thai society which has brought many benefits to cultural studies and sustained identity of each nationality

- To make new generation realize the importance of the identity of each nationality that focus on human performance which rely on environment

- Able to gain data related to identity which has been applied for future utilization

\section{ACKNOWLEDGEMENT}

- This research has been financially supported by the Graduate School, Kasetsart University

- Thessis Advisor: Associate Professor Wilaisak Kingkham, Dean of the Faculty of Humanities Kasetsart University Thailand, Thesis Advisor. Correspondence to: Wilaisak Kingkham, Faculty of Humanities, Kasetsart University Thailand. E-mail: fhumwsk@ku.ac.th

\section{REFERENCES}

Barth, F., 1969. Ethnic Groups and Boundaries: The Social Organization of Culture Difference. 1st Edn., and Unwin, London, ISBN-10: 0045720193, pp: 153.

Burapa, Y., 1993. Theptida Sumpeng. Jareonvitkarnpim, Bangkok, pp: 256.
Burapa, Y., 2005. Yu Kub Kong. 1st Edn., D. DNA, Bangkok, ISBN-10: 9749319877, pp: 287.

Cohen, A., 1985. The Symbolic Construction of Community. 1st Edn., Routledge, New York, ISBN10: 0415046165, pp: 128.

Cohen, R., 2008. Diasporas: An Introduction. 2nd Edn., Routledge, London, ISBN-10: 0415435501, pp: 192.

Fiske, J., 1991. Understanding Popular Culture. 1st Edn., Routledge, London and New York, ISBN-10: 9780415078764, pp: 206.

Hall, S., 1997. Representation: Culture Representations and Signifying Practices. 1st Edn., Sage, London, ISBN-10: 0761954325, pp: 400.

Kanokpongchai, S., 2004. Bor Bud Bor Yong Kong. 1st Edn., Seeda, Bangkok, ISBN-10: 9747727544, pp: 248.

Kennasingha, A., 1970. Botan Gleep Sudtai. 1st Edn., Puerndee, Bangkok, ISBN-10: 9789742350563, pp: 462.

Konuntakiet, C., 2006. Tungnangkia. 1st Edn., Chitra, Bangkok, ISBN-10: 9749931661, pp: 223.

Kunstadter, P., 1967. Southeast Asian Tribes, Minorities and Nations. 1st Edn., Princeton University Press, Princeton, ISBN-10: 069103057X, pp: 902.

Roojjana, L., 1980. Khaey Mai. 1st Edn., Chokchaitheves, Bangkok, ISBN-10: 2001006263, pp: 639.

Schlesinger, A. Jr., 1991. The Disuniting of America: Reflections on a Multicultural Society. 1st Edn., Whittle Communications, New York, USA., ISBN10: 0393033805, pp: 160.

Sirisingha, S., 1999. Jod Mai Jak Mueang Thai. 1st Edn., Suweeriyasarn, Bangkok, ISBN-10: 9748267555, pp: 632.

Sukda, P., 2002. Sanae Nang Gniou. 1st Edn., Soponkarnpim, Bangkok, ISBN-10: 974255382, pp: 356.

Suppasopon, S., 1983. The Chinese 200 years under the Royal Charisma. 1st Edn., Sahamitrkanpim, Bangkok, pp: 199.

Woradilok, S., 1994. Tuke Farang. 1st Edn., Dokya, Bangkok, ISBN-10: 9746024779, pp: 694. 